\title{
AFTER INTERPRETATION: REMEMBERING ARCHAEOLOGY
}

Bjørnar Olsen

We are haunted by anniversaries. Each year there is something from the past which we can celebrate, mourn about or which otherwise is regarded as sufficiently significant to be remembered. And this year, of course, is no exception. Even when we limit the scope to archaeology, and even more eccentrically to theoretical archaeology, there is actually still quite a lot that comes to mind. For example, this year marks the fiftieth anniversary of Lewis Binford's groundbreaking "Archaeol- 
ogy as Anthropology", probably the single most famous paper in our discipline, while forty years have passed since the publication of influential volumes such as An Archaeological Perspective (Binford 1972) and Models in Archaeology (Clarke 1972) (though not quite matching the revolutionary impact of Binford and Binford's New Perspectives from 1968).

Neither should the second year of the following decade have much reason for theoretical archaeological embarrassment, by allowing us now to celebrate the thirtieth anniversary of Ian Hodder's postprocessual manifestos Symbolic and Structural Archaeology and Symbols in Action (see also Flannery 1982, Leone 1982, Renfrew et al. 1982 from that annus mirabilis). Younger decadal anniversaries are for several reasons more difficult to pinpoint, but Michael Shanks' perhaps less famous but impressively relevant Experiencing the Past (1992) deserves a mention. And if we refine our search to lustrums we may from the last decades extend the list with classics such as James Deetz's In Small Things Forgotten (1977) and, of course, Shanks and Tilley's guerrilla attacks Reconstructing Archaeology and Social Theory and Archaeology ten years later (Shanks and Tilley I987a, I987b).

As probably noted, the list is entirely Anglo-American, which probably reflects both past hegemony and academic strength (see however below), but an anniversary list from Nordic archaeology could also be made quite long (e.g. Tallgren 1937; Malmer 1962; Gjessing 1977; Johansen 1982; Bertelsen et al. 1987; Olsen 1987; Johnsen \& Olsen 1992; Andrén 1997). (A note to those already agitated: this is not an exhaustive or well-researched list - even among those lucky enough to have published something relatively theoretically significant in a year ending with 2 or 7.) And if that wasn't enough reason to celebrate (the Maya calendar notwithstanding), this is the twentieth volume of Current Swedish Archaeology. Hurrah!

Anniversaries provide you with certain opportunities and excuses, also to look back and to put things into perspective - both past and present ones. Still, when asked by the editors of CSA, in light of these postprocessual anniversaries and the coming of age of this journal, to reflect on where we stand today in terms of theoretical archaeology in Sweden and Scandinavia, I hesitated. My reluctance was not only grounded in the usual stress that accompanies work and a far too perfunctory use of the interjection "yes", but also a number of doubts, uncertainties, and paradoxes. For example, and not entirely insignificant, what should count as theoretical archaeology? Why, for example, is Deetz's book, "an account of the archaeology of early American life", included in the theoretical hit parade above? Does theory (and theorizing) have to be 
explicit? Does it constitute an ontological realm distinct from practice (and doing archaeology)? Moreover, what happens with such concepts and associated divides when we stop believing in the conventional modernist hierarchy, where theory is the head and practice is the obedient acting body? Or even stop thinking that theory always intervenes and is indispensable to understanding, and instead admit that the things themselves have a say, and sometimes a very substantial one, for how meaning is arrived at (cf. Olsen 20I0; Edgeworth 20I2)? Finally, and in light of globalization and ever-expanding personal and institutional networks, are geo-political boundaries (e.g. Sweden, Scandinavia) still a pertinent framework to analyse and discuss current archaeological discourses - or do we end up "retrofitting" (Latour 1999) such entities as analytically meaningful to our inquiries?

Nevertheless, as you can see, I continued my slide down the perfunctory line and agreed to undertake this difficult and quite ungrateful task. To prepare my defence, it is important to state that this is not NOT - a scrutinizing review of theoretical trends in Scandinavian archaeology or elsewhere. Rather it is more of a personal excursion into a disciplinary landscape of the recent past, to which are added some reflections on the current state of archaeology as well as some predictions, or measured guesses, about the future. Needless to say, all this is affected by what I have done and read, by my likes and dislikes, by whom I am talking to and collaborating with, and even if the space does not allow too much extravaganza a number of subjects will undoubtedly fall through my sieve due to such biases and preferences. Still I hopefully have a few things to say about the past and the future that may be interesting to discuss. And in the safe oeuvre of archaeology let us start with the past.

\section{THEORETICAL ARCHAEOLOGY - THEN AND LATER}

In 2007 a remarkable event took place in the world of archaeological publishing. The volume Structural and Symbolic Archaeology (SSA) (Hodder I982), originating from papers presented at a theoretical fringe conference in Cambridge in I980, was reprinted. And as a further marking of its 25th anniversary the Cambridge Journal of Archaeology (CAJ) ran a discussion of the significance of the volume under the heading "Revolution Fulfilled? Symbolic and Structural Archaeology, a Generation On" (CAJ I7(2):I99-228). One of the participants, Stephen Shennan, made the following and seemingly quite common observation: 
When it first appeared Symbolic and Structural Archaeology was seen, rightly, as a revolutionary volume setting out a new direction for the discipline, in a consciously challenging manner. On re-reading it 25 years later I found the most surprising thing to be how mild and normal it all seemed. This is clearly a measure of how successful the revolution has been in changing people's attitudes... (Shennan 2007:220).

Or as the $C A J$ editors state in their introduction, "the challenger has become the establishment; the once unthinkable has become normal science" (CAJ 2007:I99). In other words, the once revolutionary manifesto of postprocessual archaeology has become everyone's archaeology. I made a similar assessment more than a decade ago in terms of the postprocessual influence on Norwegian and Swedish university archaeology (Olsen I999:I2; 2002), which already by the late I990s had become so strong and normalized that it had lost its alternative, radical image. I furthermore claimed that this "normalization" diagnosed (and explained) what seemed to be another conspicuous trend at the turn of the century: A less polemical and more calm discursive climate but also, and probably not so desirable, a decline in debates, boldness, and enthusiasm. I shall start with some personal reflections on this shift in theoretical engagement and commitment.

\section{Then}

In I98 I the small environment of graduate students in Tromsø started to sense that something strange was going on "out there", more precisely in Britain. The here still so novel "new archaeology", the main challenger to the orthodoxy of "traditional" or culture-historical archaeology, was itself under fire from archaeologists armed with structuralist, critical, and neo-Marxist theory. Early in the spring term I982 we encountered this new revolution face to face, so to speak. Ian Hodder came to lecture at the university, and one of his lectures being "Theoretical Archaeology - A Reactionary View", the paper introducing the SSA volume. I remember very well coming out of the lecture room with the feeling of having experienced something new and revolutionary; this was really something different! I also recall the excitement and enthusiasm that my fellow students and I felt in the coming years when discovering all things theoretically new: structuralism, post-structuralism, neo-Marxism, hermeneutics, etc. And this feeling of excitement reached new heights when I arrived at Cambridge in 1985 on a one-year scholarship. I probably was reasonably theoretically prepared and up-to-date after years of intense reading, but not for the completely different discursive environment I encountered (though being told, as always, that it had been even bet- 
ter some years earlier). In contrast to the mostly calm and polite Scandinavian discussions, fierce debates were waged at the packed research seminars in Downing Street, not least during the memorable seminars when Christopher Tilley and Michael Shanks presented chapters from their forthcoming "red book" (Shanks and Tilley I987b).

Why were we so excited? One reason was clearly the simple fact that we were discovering something theoretically new. Walls had collapsed, doors been opened, allowing long if not always very rewarding expeditions into new and alien territories. And the sheer fascination with the new, with the discovery itself, was clearly part of the thrill (Olsen 1999). However, an equally important reason was the feeling of making an impact, of being at a disciplinary turning point, pioneering change; in short, challenging tradition and establishment. Though some of the archaeological establishment in Sweden and Norway were positive and receptive to the new currents (e.g. Hyenstrand I988; Myhre 199I), there was still a sufficient group of patriots who saw the new ideas as a dangerous threat to the Nordic tradition and who regarded us as beset by devilish tempters from outside (see Gräslund 1989; Näsman 1995; Olsen I990; 2002:2 I 4-2I6). In other words, not much different from the reactions provoked by the new or processual archaeology some years earlier (cf. Kristiansen I978; Becker 1979; Jensen I993:I0; Hedeager 1999:22). Operating in this entrenched archaeological landscape was not without risks. However, the divides were exposed and relatively predictable, and the heated reactions the postprocessual ideas caused in some environments were just fuelling the flame. As well expressed by Silvia Tomášková when recalling how she and her fellow graduate students reacted to the disparaging reviews Shanks and Tilley's books received from American archaeologists:

Being told by an older generation of archaeologists that this was useless or even dangerous knowledge - something we students should avoid at all costs- made it all the more alluring. In retrospect the appeal of these volumes derived as much from the illicit aura surrounding them as the texts themselves. This served as the best form of advertising and encouragement to delve into post-processual theory (Tomášková 2007:2I4-2I5).

\section{Later}

Jumping to the first decade of the new millennium, the situation had become very different. At least in the Nordic countries, the UK, the Netherlands, and the USA (but probably also elsewhere), theory - including the once so "threatening and destructive" ideas of postprocessualism - was more than ever taught at universities, reflexivity and "criti- 
cal thinking" were firmly anchored in courses and curricula. Probably never before had so many archaeologists known so much about theory. As Ian Hodder put it in a turn-of-the-century paper, "Archaeologists ... are more than ever aware of the theoretical underpinnings of all data recovery, description and sequencing, and ... they are more than ever aware of the diversity of theoretical approaches being explored" (Hodder 2002:77).

At the same time this decade saw a decline in explicit theoretical debate, which, for example (and to the extent that it matters), almost vanished from the pages of the two traditionally dominant archaeological journals, American Antiquity and Antiquity (though admittedly, not exactly an avant-garde journal). One may say that we had arrived at a situation where theory was taught rather than fought. One notable sign of this educational digestion of theory was the increasing number of readers, handbooks, and textbooks available that addressed theoretical issues in archaeology. This phenomenon, en passant, just seems to be accelerating with today's handbook mania precipitated by publishing houses increasingly reluctant to take risks by producing books that cannot become textbooks. In fact, such "introductory" books serving us a gluttonous smorgasbord of varied theoretical perspectives seem now close to outnumbering those genuinely debating theory and proclaiming new perspectives.

To some commentators the development of the 2000 s was taken to signal a calmer and less polemical level of debate. The edges were rounded and theory was "made concrete and contextualised", it had become "an element of practice" (Hodder 2002:88), but also more mature and responsible, promising an "integrated archaeology, one that accepts both the dangers of constructivism and universalism, and recognizes the value of science within the framework of social and individual rights" (Hodder 2007:225). However, these proclaimed signs of a "maturing discipline", of a "widening discourse", in this first decade may also be judged very differently - as omens of an emerging new consensus (supported as well by the many claims in those days of reaching a "middle ground" based on "the best" from processual and postprocessual thinking) (e.g. Renfrew 2007). As we remember from Kuhn, an unmistaken sign of a paradigm becoming "normal science" is the calming of debates as the troops of scholars return back to business. Or, in the kindred conception of science studies, it may reflect networks in the process of being stabilized; consensus is arrived at by an increasing number of concepts, theories, methods and opinions being "blackboxed"; i.e. they are successfully internalized and taken for granted (Latour 1987, 1999). 
Nearly ten years ago, in 2003, Michael Shanks, Christopher Witmore and I discussed these issues in a paper presented at the workshop series at Stanford Archaeology Center. Here we used the term "innocence regained" (rewriting Clarke 1973) to name what we saw as theoretical trivialization and lack of boldness in the archaeology of those days:

Coming from different perspectives and positions, the three of us share a feeling that the archaeological discourse has "watered out", theory has become trivialized and lost some of its critical edge. In place of the general and bold concerns characterizing some of the new and early postprocessual archaeology, we are increasingly faced with an "issualism" - archaeologies made actual and relevant to whatever happens to be on the political and public agenda (Olsen, Shanks \& Witmore, n.d.: 2).

To others again, all this represented a timely and longed for "death of theory" - seemingly confirming all their self-imposed prejudices.

\section{ARCHAEOLOGY NOW AND TO COME}

Back in the present. As part of my preparation for this paper I started rereading $S S A$. Indeed a remarkable and important volume. Important, however, mostly as an historical artefact whose significance is confined to its impact in the past; in other words, for what it inflicted as a perfectly timed statement rather than the substance of what was said. Thus, what strikes me when reading it today (and a few other classics at hand from the I980s and I990s) is not how "mild and normal" it all seems, but actually how amazingly dated much of its focus and themes are. Reading chapter after chapter about the individual and society, actor versus structure, about the search for symbols, about material culture being structured according to underlying principles, about other compulsories such as ideology and power (and especially how they are conceived), appeared almost like being exposed to a fossil record of extinct species.

And suddenly the differences between then and now are made explicit; the changes that have taken place during the last decade, and especially during the last few years, become impossible to ignore. Likewise, it became clearer than ever that the perspectives, scopes, topics, that now are emerging cannot be seen as a "natural" continuation and development of themes and positions initiated by postprocessual archaeology. They are rather posing a radical challenge to the very grounding of this archaeology. In other words, what my modest reading exercise helped me realize more clearly is how the presumed normalized postprocessual agenda of the 1990 s and 2000 s is fragmenting. It is decaying 
and withering, exposing a ruin landscape interspersed with cracking black boxes. And with a slight shiver of déjà vu running through my body, I started thinking the unthinkable: that a new revolution is underway; more silent perhaps, but also more radical and different than the previous ones.

The finds may be few and scattered and my intellectual narcissism might have blown their significance out of proportion, but they are still there. Such that new debates are coming up and that they seem to be of a different kind, revolving around different issues (e.g. Alberti et al. 20I I; Solli et al. 20I I; Harrison et al. 20I I; Edgeworth et al. 20I 2); that new papers, books, and blogs with a different agenda, and a new way of thinking, presenting and doing archaeology, have started to emerge (e.g. Alberti and Bray 2009; Bailey et al. 20I0; Andreassen et al. 2010; Högberg 2009; Normark 20I0a; 20Iob; Olsen 20I0; González-Ruibal et al. 20II; Graves-Brown 20II; Olivier 20II; Olsen et al. 20I2; Pétursdóttir 20I2a; forthcoming; Webmoor 20I2; Witmore 20I2, forthcoming).

In the remaining part of this paper I shall contextualize these stray finds and use them to discuss a few trends which I find indicative of a new archaeology underway, which at the same time reflects both a radical departure from hegemonic archaeological ideas of the late twentieth century and a return to archaeology, the discipline of things par excellence; though a return, perhaps, to where we never have been (to borrow Alfredo González-Ruibal's wonderful phrase). Some of the trends have already become manifest while others should be classified as my predictions as to some of the probable outcomes of this new archaeology. Though most of the issues at the outset may be classified as theoretical, it still needs to be emphasized that this first and foremost is about archaeology, explaining the removal of the prefix to the subtitle above. Neither are these issues confined only to topics and thinking, but also involve the political economy of the disciplinary landscape. Thus the first trend is about the emergence of a new and perhaps less perspicuous geography of so-called international archaeology.

\section{First trend: A new geography}

Processualism and postprocessualism brought about changes not only in theoretical archaeology but also in the political economy of that archaeology. In the I980s the theoretical hegemony which American archaeology took on during the regime of the new archaeology was lost and the centre of gravity moved back to Europe (read Britain). Or as formulated by Stephen Shennan in 1986, "the days when keen young undergraduates and research students eagerly awaited the next issue of American Antiquity are long gone" (Shennan 1986:327). Needless to 
say, today the days when they eagerly awaited the next issue of Antiquity (in the unlikely case they ever did), CAJ or Archaeological Review from Cambridge are also gone. And who considers Cambridge, Southampton, or any other British academic residences as self-evident places to look for theoretical inspiration anymore?

Despite the fact that Anglo-American publishers hold an increasingly greater share of international archaeological publishing (both books and journals), and despite the fact that English is more dominant than ever before, what has been emerging - and increasingly will be emerging is a less metropolized archaeological landscape (cf. Olsen r99I). The Anglo-American dominance is and will still be strong, but the empire is withering and alternative seeds are flourishing in its cracks. Thus, as we already have started to experience, the most exciting ideas are no longer "naturally" to be expected to arrive from sites such as London, Cambridge, Southampton, Stanford, New York, or Tucson but may equally well come from Pretoria, Santiago de Compostela, Poznan, Kyushu, Lubbock, Saint-Germain-en-Laye, Oulu, Reykjavik, Stockholm, Buenos Aires, and Tromsø. Thus, when rewriting this paper in fifty years from now my anniversary list will most probably be very different from the one introducing this edition.

Another trend, perhaps more articulated in theorizing studies than elsewhere, will be the diminishing of national and regional frames for identifying archaeologies. Labels such as Swedish or Scandinavian archaeology will gradually lose their meaning as signifiers for ways of doing archaeology and even more clearly for how to approach its past. Even institutional brand naming will become less obvious as international research groups and networks (alongside mobile and partly independent researchers) will play increasingly more significant roles. This new archaeological geography is in itself, of course, no guarantee for change, nor does it provide any secure means to facilitate it. However, the new reality of simultaneous dispersal and interconnectivity provides a new and less controllable scene for archaeological reasoning.

The causes of this change are beyond the scope of this paper, but the new media reality enabling a very different presence and local-global interface clearly plays an essential role. The impact of the (relatively) new international archaeological societies, the European Association of Archaeologists (EAA) and the World Archaeological Congress (WAC), should also be taken into account by providing different venues and media for debate and publishing. And perhaps there is a certain stagnation, tiredness, and even smugness, in the once so dynamic and inspiring metropolises? Nevertheless, what is for sure is that there is no way back to the old two-party system. 


\section{Second trend: A turn to things themselves}

Recently things - and thing theory - have become a fashionable subject in the cultural and social sciences. Thus, after a century of oblivion in most social and cultural research, and after decades of linguistic and textual turns, there is now much talk about a material twist: a (re)turn to things (e.g. Preda 1999; Brown 200I; Olsen 2003; Domanska 2006; Trentmann 2009). Some have even suggested a paradigm shift; a turn away from linguistic and humanist hegemony towards posthumanism and new materialisms (e.g. Coole \& Frost 20I0; Domanska 20Io; Wolfe 20IO; Bryant 20I I; Bryant et al. 20I I; Bogost 20I2). This new intellectual climate clearly provides a major clue in accounting for the changes and debates that recently also have affected archaeology and disrupted the lull characterizing the postprocessual aftermath.

This requires some comments and clarifications raised by two anticipated objections. First objection: Isn't this just another version of the familiar old story of archaeologists as theory consumers, responding obediently to whatever happens in supposedly more vital intellectual settlements? The answer is no. Archaeologists themselves are actively and critically contributing to this redrawing of the intellectual landscape. The current situation actually constitutes a rare archaeological moment; for the first time since the late igth century the intellectual currents are in favour of us, making this situation radically different from the two previous twists and turns. While they involved importing and adapting theory developed to study (contemporary) peoples, language and text, the current intellectual fashion is about what has always been our core subject matter: things. Despite the amusing fact that some of the new protagonists seem to think the study of things is a field of their own recent invention (cf. Olsen 20I2a, 20I2b), this new materialism actually puts archaeologists in a unique position not only to make their skills relevant and to contribute significantly on the intellectual scene, but also to realize the full potential of the archaeological project.

Second objection: Why should archaeology, aptly defined as the "discipline of things par excellence" (Olsen 2003), turn to things(!)? This objection is a bit trickier and thus needs some more comments. First one should note that although archaeology consistently and faithfully has been devoted to things, its relationship with these others has remained somewhat ambiguous, being seriously affected by the shifting and often negative conceptions of things and materiality both in academia and in society at large. Moreover, and most crucial, there is an addendum to the naming of this predicted turn: To the things themselves. Indeed, both we and the fast-growing hoards of new thing friends have during 
the last decades assigned more importance to things; they've been let in from the cold and made actors and constitutive members of society, which increasingly is normalized as a heterogeneous assemblage of people, things and other non-humans (e.g. Gell 1998; Latour 1993, 2005). What seems less cared for in all these brave repatriation attempts is the otherness of things: What happens to their thingness and integrity when expected to feature in those currently popular anthropomorphized roles as actors, extended persons, delegates? Is it just accidental that their entry permit into society seems to prescribe a mode of being that complies surprisingly well with that of the former prime residents? In other words, to what extent has this sudden generosity actually contributed to their assimilation and domestication (Pétursdóttir 20I2)? Thus there might be some unintentional irony to Latour's claim that "the more nonhumans share existence with humans, the more humane a collective is" (Latour 1999:I8, emphasis modified). Though assigning things human qualities may be understood sympathetically as an initial strategic move in order to include them, not very different from early functionalist anthropology's rationalization of the others' exoticism by showing them basically as us (i.e. as rational and calculative actors) (Sahlins I976:7475), the next - and really radical step - involves the difficult task of recognizing things as things. And it is my conviction that archaeology and our heterogeneous portfolio of materials essentially can help facilitate such a turn to things, one more radical than much current thing theory seems to imply.

Unlike some of the new thing-friendly environments, archaeology is of course the discipline of all things, of everything, no matter how outdated, incomplete, unexciting, or repulsive. And if we think about it, what things could be better fit to articulate a thingly otherness than the messier of our archaeological objects? What things could more resolutely and effectively oppose the humanizing and interpretative exploitation than smashed pots, slag lumps, flint debris, caulking resins, burnt bones, fire-cracked rocks, broken slate tools, hammer stones, and sinkers; the bulky material redundancy of the past filling our museum cellars, storage rooms, and labs? Things discarded, lost, and forgotten but which stubbornly remain, things that object to that persistent image of the past as gone; things which in their assembly, gathering, and bonding resist temporal ordering and chronological sequencing; things which defy completeness and system and which constantly affect us by their sheer physiognomy and raw bulk. What a potent and powerful assemblage - though strangely enough not figuring very prominently on the new thing adherents' repatriation lists - compared to, for example, Boyle's air pump, the body, Henry James's novels about things, pros- 
theses, and intelligent design (Olsen 20I2a, 2012b). And perhaps the archaeologists shouldn't be too loud-mouthed either, not always being very generous with the ordinary and numerous, the messy and defiant, those nothings which often resist naming and classification.

Nevertheless, what we should do is to stop concealing and taming this otherness, which also means an end to our current obsession with turning mute things into storytellers or otherwise loading them with interpretative burdens they mostly are unfit to carry. Thus I suggest that a move towards things as things implies a farewell to current regimes of interpretation and intellectualization. This modest suggestion constitutes my next predicted trend.

\section{Third trend: farewell to interpretation}

Predicting a farewell to interpretation is not about abolishing interpretation in its modest and inevitable form, but an overdue objection to the constant intellectual urge to think that the immediate and directly perceived, the ordinary and everyday, is less interesting, less meaningful, than the hidden and abstracted. Reading recent books and papers on Scandinavian rock art, just to take a random example, one will find that a boat, an elk or a reindeer can be claimed to represent or signify almost everything - ancestors, rites of passage, borders, totems, gender, supernatural powers, etc. - apart, it seems, only from themselves. A boat is never a boat; a reindeer is never a reindeer; a river is always a "cosmic" river. Why, for example, does it seem more intellectually pleasing to suggest that the "shore connection" (the case that the rock carvings of northern Scandinavia and north-west Russia are mostly located in shore areas) is about cosmology, liminality and transcendence (Helskog I999), rather than about the fact that the rocks along the shore themselves are attractive and inviting for such depicting practices by being polished by the sea and free of the soil and vegetation covering higher rocks? Why is the latter option, which gives the rock and the sea a say, less interesting than the cognitive reading?

There seems to have been a persistent assumption within material culture studies and postprocessual or interpretative archaeology that the sexiest significance of things always lies in their metaphorical, representative or embodied meanings. Intellectually satisfying meanings are rarely about the objects in question or about the immediate and directly perceived but always derivative, something embodied or inscribed by some human source, whereby interpretation inevitably becomes the tracing of this extra-material origin. Fortunately, as archaeologists rediscover that the habitual and everyday uses of things are not something of interest only to "folk" studies or to an archaeology long 
past, this conflation of meaning with symbolic and metaphorical abstraction is increasingly challenged (e.g. Högberg 2009, Nordby 20I 2). Sharing conviction with the people we so eagerly have longed to reach, more and more archaeologists, even the most abstracted among us, will start to realize that such engagements with things, animals, and other natures are far from trivial, in the derogatory sense of the word, but imply knowledge, care, and attachment, and a respect for what things are in their own being.

Moreover, as the idealist and anthropocentric grip on our reasoning slowly loosens we will also start to accept more readily, and again, I guess, on a par with our ancestors, that things also may be the source of their own signification. That a boat, for example, is mostly significant for what it is - that is, being a boat. It is significant due to its material integrity and for what it offers of boat qualities. This relates to the knowledge, skill and materials it assembles; its persistency and reliability, the capacities it possesses in terms of speed, stability, mastering of winds and waves, for the activities it enables such as transport, fishing, hunting, fighting, as well as for its beauty and the joy and excitement it affords. In a similar way an axe is significant primarily due to its unique axe qualities; a reindeer due to its inherent and multiple reindeer qualities (Olsen 2010:155-I57). This, of course, is not to dismiss that these entities also may act as symbolic or cognitive devices, but to argue that such qualities are themselves often connotative residues triggered by the primary significance of their own material being.

A new concern with the ordinary, everyday, and real, with things in themselves, will also facilitate a new turn to phenomenology; though one very different from the one attempted by (mostly) British archaeologists in the I990s and 2000s. By pretending that phenomenology was just another interpretative device that could be applied to understand (of all things!) monumentalism (e.g. Tilley 1994, 2004; Thomas 1996; Hamilton et al. 2006; Bender et al. 2007), this attempt blatantly exemplifies the fallacies of clothing the past in an interpretative straitjacket. While phenomenology, more than anything, was about the ordinary and everyday, a bold attempt at "relearning to look at the world", "a return to the world of active experience" unobscured by abstract philosophical concepts and theories, which also and essentially involved a return to "the things themselves" (cf. Heidegger I962:58; Merleau-Ponty I962:57-58; I968:4), it was rather the opposite that became an issue of concern in its archaeological guise. Leaving us with a phenomenological archaeology strangely alienated from the everydayness of herding sheep, clearing fields, carrying water, cutting woods, building fences, cooking, and feeding. While apparently not exciting enough for the in- 
terpretative archaeologists, ${ }^{\mathrm{I}}$ is precisely with regard to these archaeological matters that phenomenology, and in particular Heidegger's work, still has a lot to offer. Not least of all, it may help us unlearn the processual and postprocessual imperative of theory as indispensable to understanding and help us to trust in our own perception, in things themselves and what they articulate in their own and peculiar material manner. In other words, and seemingly somewhat paradoxical, phenomenological "theory" may help us realize the simple fact that there are other paths to archaeological knowledge besides theory.

A final note to this section: In the unlikely case that you suspect that this return to things themselves, to the everydayness of human life, will make your archaeological being dismal and intolerable, I suggest a diagnostic test - and cure: Use the previous postprocessual/interpretative standards (leaving little room for the immediate, for ready-at-hand things, for life and being as commonly lived and experienced, or for care, affection, or joy) to assess your own life. Given those airy requirements for meaning and significance, how many of us, truly speaking, live interesting and meaningful lives?

\section{Fourth trend: archaeology as archaeology}

Archaeology has by all means a great - and in an academic context largely unrivalled - legacy in caring for things; humble things, broken things. As archaeologists we work with the messy spoils of history; in fact, it can be claimed that the outdated, the fragmented, the discontinuous, and the silent is our lot. This constitutes a disciplinary difference of great significance, as Michel Foucault correctly, if somewhat superficially, realized. So far, however, the potential of this archaeological difference is a largely unredeemed capital. The constant urge to write cultural history, conduct social analysis, or to bring to life thoughts and cultures long past, has, as already noted, made it tempting to rush past the masses of trivial and broken things to aim at the more unusual, conspicuous, and alluring materialities which faithlessly promise easier access to the wished-for realms of "behind".

Indeed, the persistent attempts to make our messy archaeological portfolio comply with the ever-present imperatives of History and Society have rather emphasized its inferiority, and despite all middle-range

1 When finally realized by the interpretative archaeologists that phenomenology was about this mundaneness of the ready-to-hand, it was doomed "inadequate", a descriptive exercise which had to be fleshed out with a "hermeneutics of interpretations", exploiting "metaphoric and metonymic linkages between things" (Tilley 2004:224). 
magic often made our histories and sociologies seem embarrassingly trivial and incomplete. The time thus seems overdue to give up these airy ambitions which in any case are doomed to render things (and archaeology) secondary and instead to aim at archaeology - an archaeology of the past and the present (see González-Ruibal forthcoming). Rather than seeing this as a retreat or a loss, giving up the brave processual and postprocessual ambitions, it is actually a far bolder move. It is the seizure of our disciplinary grounds - and an act of empowerment which challenges the almost ontologized confusion of the past with history as well as the equally taken-for-granted assumption of the present as non-archaeological territory. As noted by Póra Pétursdóttir (20I2), while archaeology has often been critical of history, we have still remained positive to deconstructing and rewriting it; in other words, to produce alternative histories rather than being an alternative to history (see Olivier 20II).

In order to start moving in this direction we need to stop seeing the archaeological record as a problem, as representing loss, failure, or defect, something we must correct by filling in the gaps in order to heal the material past as history. Such a release from the historical straitjacket involves trying out another and perhaps more viable option: to let this "record" be fragmented and incomplete, to let things also be trivial and banal, in short, to let them be things - and allow their otherness to affect and be part of the archaeology we produce. This is an archaeology that sacrifices historical narratives in favour of a trust in its own ruined things, things that emerge from and bring forth a different past: one which accumulates and disrupts, being "at once scattered and preserved" (Benjamin 1996:169). And if we need a model, an analogy, or a trope for such an archaeological engagement with the past, it is, as Laurent Olivier has argued, probably far better served by memory than history (Olivier 20II). In other words, as fragmentary, disorderly presences that disrupt the projected stream of historical time and the associated expectations of the "have been" and the becoming.

And one initial and obvious move by which to realize this archaeological otherness is to show how things in their very own positivistic manner object to the finitude and pace of history. Although ageing and transforming, these ingredients and residues of supposedly ended or replaced pasts stubbornly linger on and gather around us. Look out of your window or around you wherever you are - is the past gone? Does what you see date to the present; a purified and sliced now? Continue by considering what we as archaeologists encounter during an excavation and the way the past here is disclosed to us. Recall superimposed structures, artefacts and debris mixed together, different pasts and dif- 
ferent dates compressed and flattened out; in short, materials that object to modernity and historicism's wished-for ideal of completeness, order, and purified time. Rather than seeing this hybridized material record as a distortion of an originally pure historical order existing beyond and prior to the entangled mess we excavate and which we thus need to restore, we should start taking it seriously as an expression of how the past actually gathers in the present, defying the temporal specificity, sequential order, and finitude that we have been obsessed with (Olsen 20I0:I26-I28). In fact this gathering is as normal and true for the past sites we study as for the present ones we live in. As little as the Stockholm you encounter can be dated to a particular time without losing what constitutes its present being as a chronological hybrid formed by a constantly gathering past (enabled by the persistency of things), as little can we cleanse the sites we excavate without at the same time depriving them of the pasts that grounded their presents. In this sense, the palimpsestal archaeological record provides a far more realistic and accurate image of the past than any historical narrative.

Archaeology also differs from history by the way our work involves and necessitates direct encounters with the very material past we study. This in itself is a crucial difference and also involves very significant experiences and engagements that unfortunately are rarely allowed any presence in our analyses and disseminations. Aspects of these encounters are exemplified in the sensation felt by suddenly being exposed to (and yes, discovering) a chert blade not seen or touched by other humans for thousands of years, by finding a bundle of pipe cleaners in a turf-covered floor layer at a northern PoW camp, or the numerous and ineffable presence effects triggered when making your way through an abandoned herring factory. All these sensations are part of the archaeological thrill, of what makes archaeology different and attractive, also in public opinion (Holtorf 2004), but which often has been rendered trivial, extra-scientific, or even embarrassing in our endeavour to become real and respectable (social) scientists and culture historians. Fieldwork is rightly seen as imperative to our archaeological being, and the direct and often long engagements with sites, places, peoples, and landscapes are not just about "collecting data". Working with heath, gravel, and stone, interacting with people and animals, with wasps, mosquitoes, and terns; being exposed to views, sounds, and smell from land and sea, to weather of all kinds, trying to accommodate your camp and everyday needs to what the place affords you, brings an experiential dimension to our archaeological reasoning that generally is far too underrated. Without much pretension to the usefulness of "reenactment", I am still convinced that a rich archaeological and material engagement with a place 
or a region also makes us manifest its past differently. It is after all very different from reading about a place in the comfort of our study (Olsen et al. 20I2). As evocatively expressed by Colin Renfrew when recalling:

the parched days under a hot sun in Greece, the pouring rain and sustained wind on the day at Quanterness when, working together as a team, we had to backfill that west section in the course of a few hours, and never mind the weather. But also the sense of mystery and solitude when I was the first to enter, perhaps for thousands of years, one of the side chambers at Quanterness and stand up with the cold, damp sandstones all around me, and reach my hand above my head to touch the still complete corbelling of the ceiling. You don't find much about these moments in the printed excavation report, but they are an integral part of the reality (Renfrew 2003:39-40).

To aim for archaeology as archaeology is also to allow for this difference to become manifest, also outside the rare "special" or "artistic" publications, such as the one where Renfrew finally could articulate this truly "integral part" of the archaeological reality (Renfrew 2003). In order to do so archaeologists need to become more "descriptive" again (Pearson and Shanks 2001:64-65), even to let ourselves be inspired by the descriptive richness the antiquarians aimed at, which also is manifested in the accounts left us by explorers and "adventurers" such as Fridtjof Nansen, Knud Rasmussen, and Helge Ingstad. The challenge is to produce rich descriptive accounts that also understand, not by heading beyond things and the immediate world, or by leaving out what arises in the momentary presence of encounter, but by allowing them a rightful share. Living in a rapidly changing media reality the range of possibilities for such "descriptive" richness is of course potentially endless, but regardless of format, what we need is more creativity, more playfulness and less trade of ready-digested interpretations (Andreassen et al. 2010). Giving things and other beings a say also involves making their presence more immediate and weighty in our disseminations, allowing for extended and distributed presence effects and encounters, beyond those formerly reserved for the archaeologists.

\section{Conclusion}

Owing to the modern regime's effective impact during the last 200 years, it has been difficult to think of the past outside succession, replacement, temporal order, and causation; outside the imperative of history. It has been equally difficult to think of meaning and significance outside the human intentional realm, or of understanding as something that does not take us beyond the immediate and the everyday. The pivotal role assigned to the human subject still makes it hard to think of the world as 
co-produced and ontologically relatively egalitarian. So-called postmodernism did little to alter that. Despite the programmatic decentring of the human subject we were left with a humanly constituted world where no power or significance could arrive from outside the human realm.

Thus, needless to say, the obstacles to a new archaeology are tough. Nevertheless, there are signs of more far-ranging changes and ruptures that will help us fight these obstacles. These changes, which are starting to make a strong impact across the disciplinary landscape (and which archaeologists also contribute to), are manifested under a number of labels such as posthumanism, new ecology, new empiricism, speculative empiricism, and, of course, a (re)turn to things/materialism. As already argued above, rather than seeing these potentially paradigmatic changes, which all somewhat superficially can be said to opt for a "return of the real", as something alien and threatening to the archaeological project, they may actually provide the very conditions that enable us to fully realize its great potential.

Though there are of course quite a few archaeologists that support or are sympathetic to the change of course proposed here, the numbers relative to the profession as a whole are probably very small. This situation in and of itself, however, is not unique to this proposed turn; even in their heyday neither the processual nor the postprocessual camp could claim support from more than a small minority of the world's archaeologists. And unlike previous attempts at change, the current one can count among its strengths that it is not about sacrificing archaeology for something else (anthropology, philosophy, literary criticism, hard sciences, etc.), it is not about turning things into language or text (or "extrasomatic means of adaptations"). Rather it is about having trust in our own project and in what archaeologists hold dearest: Things. It should also provide further reassurance to a few that this is not about making archaeology more theoretical, abstract, and elitist but rather an acknowledgement that knowledge and understanding also emerge from practice and mindful engagements with ditches, layers, relic walls, hearths, slab-lined pits, abandoned mining towns or last week's rubbish. It thus even allows for the almost forgotten possibility that knowledge sometimes is revealed rather than produced.

A concern with things themselves, exploring their intrinsic qualities, is indispensable to any archaeology. This concern should not be restricted to how they affect and mix with humans, but should also include an interest in how they are among themselves; how they relate and act upon each other (an interaction so far mostly acknowledged in archaeological science and environmental and behavioural archaeology) (though see Hodder 20I2, Nordby 20I2). From this concern will also 
develop a more general interest in the "co-production" of the past, both in terms of how humans have engaged in indeterminate hybrid relations with other beings and how these other beings themselves, independently of humans, have affected and constituted the world we share with them (Olsen 20I2c). In short, we will see a release from the humanist imperative that humans are a fundamental ingredient in every relation of interest, which also will spark off a new and more diverse interest in ecological approaches in archaeology.

Since this move and much of what otherwise is said in this paper at the outset may be seen as complying with a posthumanist stance (Domanska 20Iо; Wolfe 20IO), and clearly is challenging the taken-for-granted human primacy, it is easily doomed as anti-human, and thus may not appear very attractive to what traditionally is seen as a humanities discipline or a human science. Succinctly, and this needs to be stated, a turn to things does not represent any disinterest in people. However, it implies a change of focus from humans as the overarching objective, that "getting at people is the core activity in archaeology" (Gamble 200I:73), into a concern with more humble humans as democratized beings amongst other beings, with humans as a companion species, albeit a crucial one. What we increasingly will see are also new perspectives for how humans relate to these other beings. As new ethical concerns are emerging (Benso 2000; Introna 2009; Olsen et al. 20I2; Pétursdóttir 20I3), the focus will change from things, animals and natures as primarily beings-for-us (technology, resources, for consumption and use) into beings of concern and care, and even as beings-for-themselves (Heidegger 1966:46-55). In other words, we will see perspectives where issues of care and concern will play a more prominent role for how to conceive these relations, issues that also pertain to respecting the integrity and otherness of things and natures.

Whatever will happen we have to be prepared for surprises, disappointments, but hopefully mostly a new and more interesting archaeology. To be sure, studying how things are in themselves and among themselves may not comply well with our current interpretative ambitions and expectations. Things can be unruly and disorderly, behave in ways banal, trivial or downright boring, and they may well conspire against the wish image of a readable record providing smooth access to a past or present world behind. They may, in short, simply refuse to be useful and fiercely object to the ridiculously heavy interpretative burdens that have been placed on their shoulders. And this, of course, is their damned right. However, and to stay tuned with the anthropocentric vocabulary criticized (and now reintroduced), if we take the trouble to listen to what they actually do know something about, they may have a lot to reveal 
about themselves, the present, and the past. Expect no grand narratives, of course, and not very much about History and Society, but do look forward to a lot of memories which have escaped historical consciousness, memories of that which is regarded as self-evident, as too ordinary or trivial, or too embarrassing or grim to be spoken and written about. Things after all are less inclined to discriminate, caring also for the outdated and stranded, the neglected and unwanted. And again, in the very unlikely case that you find this archaeology tedious, unrewarding, blatant, or repulsive, I have no other consolation than the prediction that what you will find most surprising in thirty years from now is how "normal and mild" this all sounds.

Bjørnar Olsen

Departement of Archaeology and Social Anthropology Faculty of Humanities, Social Sciences and Education University of Tromsø 9037 Tromsø Norway

\section{ACKNOWLEDGEMENT}

I owe many thanks to Póra Pétursdóttir and Chris Witmore for reading and commenting on earlier drafts of this paper.

\section{REFERENCES}

Alberti, B. \& T. L. Bray (Eds). 2009. Animating Archaeology. Of subjects, objects and alternative ontologies. A Special Section for Cambridge Archaeological Journal I9(3): 337-44I.

Alberti, B., Fowles, S., Holbraad, M., Marshall, Y. \& Witmore, C. 20I I. Worlds Otherwise. Archaeology, Anthropology and Ontological Difference. Current Anthropo$\log y$ 52(6): 896-9I2.

Andreassen, E., Bjerck, H. \& Olsen, B. 20Io. Persistent Memories. Pyramiden - a Soviet Mining Town in the High Arctic. Trondheim: Tapir.

Andrén, A. 1997. Mellan ting och text. En introduktion till de historiska arkeologierna. Stockholm: Brutus Östlings Bokförlag Symposium

Bailey, D., Cochrane, A. \& Zambelli, J. 20Io. UNEARTHED. A Comparative Study of Jomon Dogu and Neolithic Figurines. Norwich: Sainsbury Centre for Visual Arts.

Becker, C. J. 1979. Arkeologien i Danmark - i går, i dag og i morgen. Fortid og Nutid XXVIII:3-II.

Bender, B., Hamilton, S. \& Tilley, C. 2007. Stone Worlds. Narrativity and Reflexivity in Landscape Archaeology. Walnut Creek, CA: Left Coast Press.

Benjamin, W. 1996. Central Park. In Selected Writings, vol. I: 1913-1926. Cambridge, Mass.: Belknap Press. 
Benso, S. 2000. The Face of Things. A Different Side of Ethics. Albany: State University of New York Press.

Bertelsen, R., Lillehammer, A. \& Næss, J. R. (Eds). 1982. Were They All Men? An Examination of Sex Roles in Prehistoric Society. Acts from a workshop held at Utstein Kloster, Rogaland, 2.-4. November 1979. Stavanger: Arkeologisk Museum.

Binford, L. 1962. Archaeology as Anthropology. American Antiquity 28(2). Pp. 2 I7-25.

Binford, L. 1972. An Archaeological Perspective. New York: Seminar Press.

Binford, S. \& Binford, L. 1968. New Perspectives in Archaeology. Chicago: Aldine Press.

Bogost, I. 20I2. Alien Phenomenology, or What It's Like to Be a Thing. Minneapolis: University of Minnesota Press.

Brown, B. 200I. Thing Theory. Critical Inquiry 28. Pp. I-22.

Bryant, L. 20I I. The Democracy of Objects. Ann Arbor: Open Humanities Press.

Bryant, L., Srnicek, N. \& Harman, G. (Eds). 20I I. The Speculative Turn. Continental Materialism and Realism. Melbourne: re.press.

Clarke, D. (Ed.). 1972. Models in Archaeology. London: Methuen.

Clarke, D. 1973. Archaeology: The Loss of Innocence. Antiquity 47. Pp. 6-I8.

Coole, D., \& Frost, S. 2010. New Materialisms. Ontology, Agency, and Politics. Durham: Duke University Press.

Deetz, J. 1977. In Small Things Forgotten. The Archaeology of Early American Life. New York: Anchor Books.

Domanska, E. 2006. The Return to Things. Archaeologia Polona 44. Pp. I7I-I85.

Domanska, E. 20Io. Beyond Anthropocentrism in Historical Studies. Historein Io. Pp. II8-I30.

Edgeworth, M. 20I2. Follow the Cut, Follow the Rhythm, Follow the Material. With comments from A. Berggren, A. González-Ruibal, T. Ingold, G. Lucas, R. Skeates, \& C. Witmore. Norwegian Archaeological Review 45(I). Pp. 76-I I4.

Flannery, K. I982: The Golden Marshalltown. A Parable for the Archaeology of the I980s. American Anthropologist 84(2). Pp. 265-78.

Gell, A. 1998. Art and Agency. An Anthropological Theory. Oxford: Oxford University Press.

Gjessing, G. I977. Idéer omkring førhistoriske samfunn. Universitetets Oldsakssamlings Skrifter, ny rekke, nr. 2. Oslo: Universitetets Oldsakssamling.

González-Ruibal, A., Hernando, A. \& Politis, G. 20I r. Ontology of the Self and Material Culture: Arrow-making among the Awá Hunter- Gatherers (Brazil). Journal of Anthropological Archaeology 30(I). Pp. I-I6.

González-Ruibal, A. (Ed.). (forthcoming). Reclaiming Archaeology. Beyond the Tropes of Modernity. London: Routledge (to be published February 2013).

Gräslund, B. I989. Den arkeologiska teorins uppgift och bruk. Fornvännen 84.Pp.47-50.

Graves-Brown, P. 20I I. Touching from a Distance. Alienation, Abjection, Estrangement and Archaeology. Norwegian Archaeology Review 44(2). Pp. I3 I-44.

Hamilton, S., Whitehouse, R., Brown, K., Combes, P., Herring, E. \& Seager Thomas, M. 2006. Phenomenology in Practice. Towards a Methodology for a "Subjective" Approach. European Journal of Archaeology 9(I). Pp. 3I-7I.

Harrison, R. 20I . Surface Assemblages. Towards an Archaeology in and of the Present. With replies from A. Horning, A. González-Ruibal, P. Graves-Brown, I. Russel \& W. Rahtje Archaeological Dialogues i8(2). Pp. I4I-96. 
Hedeager, L. \& Oma, K. I999. Intervju med Lotte Hedeager. Nicolay I999. Pp. 22-25. Heidegger, M. 1962. Being and Time. New York: Harper and Row.

Heidegger, M. I966. Discourse on Thinking. Anderson, J. M. \& Freund, E. H. (trans.). New York: Harper and Row.

Helskog, K. 1999. The Shore Connection. Cognitive Landscape and Communication with Rock Carvings in Northernmost Europe. Norwegian Archaeological Review 32(2). Pp. 73-94

Hodder, I. (Ed.). I982a. Structural and Symbolic Archaeology. Cambridge: Cambridge University Press.

Hodder I. I982b. Symbols in Action. Ethnoarchaeological Studies of Material Culture. Cambridge: Cambridge University Press.

Hodder, I. 2002. Archaeological Theory. In: Cunliffe, B., Davies, W. \& Renfrew, C. (Eds). Archaeology. The Widening Debate. Oxford: Oxford University Press.

Hodder, I. 2007. Can We Move On Now? Cambridge Archaeological Journal I7(2). Pp. 213-2I7.

Hodder, I. 20I 2. Entangled. An Archaeology of Relationships between Humans and Things. Oxford: Wiley-Blackwells.

Holtorf, C. 2004. Doing Archaeology in Popular Culture. In: Bolin, H. (Ed.). The Interplay of Past and Present. Södertörn Archaeological Studies. Huddinge: Södertörn University College.

Hyenstrand, Å. (Ed.). I988. Sambällsteori och källmaterial-aktuell arkeologiII. Stockholm Archaeological Reports 2I. Stockholm: University of Stockholm.

Högberg, A. 2009. Lithics in the Scandinavian Late Bronze Age. Sociotechnical Change and Persistence. BAR International Series I932. Oxford: Archeopress.

Introna, L. D. 2009. Ethics and the Speaking of Things. Theory, Culture and Society 26. Pp. 398-4I9.

Jensen, J. I993. Introduction. 25 years of archaeology in Denmark. In: Vass, S., Storgaard, B. \& Lund Hansen, U. (Eds). Digging Into the Past. 25 Years of Archaeology in Denmark. Copenhagen: Royal Society of Northern Antiquaries.

Johansen, A. B. I982. Arkeologiens teori og data. Fornvännen 77. Pp. 212-225.

Johnsen, H. \& Olsen, B. 1992. Hermeneutics and Archaeology. On the Philosophy of Contextual Archaeology. American Antiquity 57(3). Pp. 4I9-436.

Kristiansen, K. 1978. Dansk arkæologi - fortid og fremtid. Fortid og Nutid XXVII. Pp. 279-3I9.

Latour, B. 1987. Science in Action. How to Follow Scientists and Engineers through Society. Cambridge, Mass.: Harvard University Press.

Latour, B. I993. We Have Never Been Modern. Cambridge, MA: Harvard University Press.

Latour, B. 1999. Pandora's Hope. Essays on the Reality of Science Studies. Cambridge, MA: Harvard University Press.

Latour, B. 2005. Reassembling the Social. An Introduction to Actor-Network-Theory. Oxford: Oxford University Press.

Leone, M. I982. Some Opinions about Recovering Mind. American Antiquity 47(4). Pp. 742-760.

Malmer, M. 1962. Jungneolithische Studien. Acta Archaeologica Lundensia, Series in $8^{\circ}$ No. 2. Lund: CWK Gleerups Förlag. 
Myhre, B. I991. Theory in Scandinavian Archaeology since 1960. A view from Norway. In: Hodder, I. (Ed.). Archaeological Theory in Europe. The Last Three Decades. London: Routledge.

Näsman, U. 1995. Finns en nordisk tradition i dagens nordiska arkeologi? Nicolay 65/66. Pp. 9-I5.

Nordby, C. 20I2. Gjemt og glemt? Harpikstetninger fra eldre jernalder - en forskningshistorisk gjennomgang. Viking 75/2012 (in press).

Nordmark, J. 20Ioa. Face/Off. A Neomaterialist Study of the Face. In: Fahlander, F. \& Kjellström, A. (Eds). Making Sense of Things. Archaeologies of Sensory Perception. Stockholm Studies in Archaeology 53. Stockholm: Stockholm University.

Nordmark, J. 20Iob. Involutions of Materiality. Operationalizing a Neo-materialist Perspective through the Causeways of Ichmul and Yo'okop, Mexico. Journal of Archaeological Method and Theory I7(2). Pp. I32-I73.

Olivier, L. 20I I. The Dark Abyss of Time. Archaeology and Memory. Lanham, MD: AltaMira Press.

Olsen, B. 1987. Arkeologi, tekst, samfunn. Fragmenter til en post-prosessuell arkeologi. Stensilserie B, historie/arkeologi 24. Tromsø: University of Tromsø.

Olsen, B. 1990. Språk og retorikk i arkeologien. Fornvännen 85. Pp. II5-I I9.

Olsen, B. I99I. Metropolises and Satellites in Archaeology: On Power and Asymmetry in Global Archaeological Discourse. In: Preucel, R. W. (Ed.). Processual and Postprocessual Archaeologies. Multiple Ways of Knowing the Past. Occasional Paper Io. Carbondale, Ill.: Center for Archaeological Investigations.

Olsen, B. 1999. Back to the Eighties? In: Fuglestvedt, I., Gansum, T. \& Opedal, A. (Eds). Et hus med mange rom. Vennebok til Bjørn Mybre på 60-års dagen. AMSRapport i IA, Stavanger: Arkeologisk Museum.

Olsen, B. 2002. Divided We Stand? Some Opinions about Trends and Developments in Scandinavian Archaeology 1970-2000. In: Biehl, P. F., Gramsch, A. \& Marciniak, A. (Eds.). Archäologien Europas. Geschichte, Methoden und Theorien. Tübinger Archäologische Taschenbücher 4. Münster: Waxmann Verlag.

Olsen, B. 2003. Material Culture after Text: Re-membering things. Norwegian Archaeological Review 36(2). Pp. 87-104.

Olsen, B. 20Io. In Defense of Things. Archaeology and the Ontology of Objects. Lanham, MD: AltaMira Press.

Olsen, B. 20I 2a. The Return of Things and the Savagery of the Archaeological Object. In: Pereira, G. (Ed.). Savage Objects. Lisboa: Imprensa Nacional Casa da Moeda (INCM).

Olsen, B. 20I 2b. Reclaiming Things. An Archaeology of Matter. In: Carlile, P. R., Nicolini, D., Langley, A. \& Tsoukas, H. (Eds). How Matter Matters. Objects, Artifacts and Materiality in Organization Studies. Oxford: Oxford University Press.

Olsen, B. 20I 2c. Symmetrical Archaeology. In: Hodder, I. (Ed.). Archaeological Theory Today. Cambridge: Polity Press.

Olsen, B., Shanks, M., Webmoor, T. \& Witmore, C. 20I2. Archaeology. The Discipline of Things. Berkeley: University of California Press, Berkeley.

Olsen, B., Shanks, M. \& Witmore, C. n.d. Innocence Regained? Or, Is There a New Consensus in Archaeology? An Alternative Case for Bold Thinking. Paper presented at the Stanford Archaeology Center's Workshop series, October 2003.

Pearson, M., \& Shanks, M. 200I. Theatre/Archaeology. London: Routledge. 
Preda, A. 1999. The Turn to Things. Arguments for a Sociological Theory of Things. Sociological Quarterly 40. Pp. 347-366.

Renfrew, C. 2003. Figuring It Out: What Are We? Where Do We Come From? The Parallel Visions of Artists and Archaeologists. London: Thames and Hudson.

Renfrew, C. 2007. Where Did It All Go Wrong? Cambridge Archaeological Journal I7(2). Pp. 220-22I.

Renfrew, C., Rowlands, M. J. \& Seagraves, B. A. (Eds). 1982. Theory and Explanation in Archaeology. The Southampton Conference. New York: Academic Press.

Sahlins, M. 1976. Culture and Practical Reasons. Chicago: University of Chicago Press.

Shanks, M. 1992. Experiencing the Past. London: Routledge.

Shanks, M., \& Tilley, C. I987a. Reconstructing Archaeology. Theory and Practice. Cambridge: Cambridge University Press.

Shanks, M. \& Tilley, C. 1987. Social Theory in Archaeology. Cambridge: Polity Press.

Shennan, S. I986. Towards a Critical Archaeology? Proceedings of the Prehistoric Society 52 . Pp. 327-338.

Shennan, S. 2007. Evolving Ideas. Cambridge Archaeological Journal I7(2). Pp. 220-22I.

Solli, B. 2or r. Some Reflections on Heritage and Archaeology in the Anthropocene. With Replies from M. Burström, E. Domanska, M. Edgeworth, A. González-Ruibal, C. Holtorf, G. Lucas, T. Østigaard, L. Smith \& C. Witmore. Norwegian Archaeology Review 44(I). Pp. 40-88.

Tallgren, A.M. 1937. The Method of Prehistoric Archaeology. Antiquity I r. Pp. 152-I6I.

Thomas, J. 1996. Time, Culture and Identity. An Interpretive Archaeology. London: Routledge.

Tilley, C. 1994. A Phenomenology of Landscape. London: Berg.

Tilley, C. 2004. The Materiality of Stone. Explorations in Landscape Phenomenology. Oxford: Berg.

Tomášková, S. 2007. Post-processual Archaeologies. Through a Stained Glass (Not Darkly). Cambridge Archaeological Journal I7(2). Pp. 2I3-2I7.

Trentman, F. 2009. Materiality in the Future of History. Things, Practices, and Politics. Journal of British Studies 48. Pp. 283-307.

Pétursdóttir, P. 20I 2. Small Things Forgotten Now Included, or What Else Do Things Deserve? International Journal of Historical Archaeology I6 (published online 4 August).

Pétursdóttir, P. Forthcoming (20I3). Concrete Matters. Ruins of Modernity and the Things Called Heritage. Journal of Social Archaeology I3(I).

Webmoor, T. 20I2. An Archaeological Metaphysics of Care. On the Isotopy of the Past(s), Epistemography and Our Heritage Ecologies. In: Fortenberry, B. \& McAtackney, L. (Eds). Modern Materials. Proceedings from the Contemporary and Historical Archaeology in Theory Conference 2009. Oxford: British Archaeological Reports.

Witmore, C. 20I 2. The Realities of the Past. In: Fortenberry, B. \& McAtackney, L. (Eds). Modern Materials. Proceedings from the Contemporary and Historical Archaeology in Theory Conference 2009. Oxford: British Archaeological Reports.

Witmore, C. Forthcoming (20I3). The New Materialisms. Archaeological Dialogues. Vol. 20.

Wolfe, C. 20Io. What is Posthumanism? Minneapolis: University of Minnesota Press. 